\title{
Analysis of Elementary School Headmaster Candidate's Competence in Jombang East Java
}

\author{
Desi Eri Kusumaningrum \\ Department of Educational Administration, Faculty of \\ Education, State University of Malang \\ East Java, Indonesia \\ Djum Djum Noor Benty \\ Department of Educational Administration, Faculty of \\ Education, State University of Malang \\ East Java, Indonesia
}

\author{
Raden Bambang Sumarsono \\ Department of Educational Administration, Facullty of \\ Education, State University of Malang, Jl. Semarang 5 \\ Malang, East Java, Indonesia 65145. \\ raden.bambang.fip@um.ac.id
}

\begin{abstract}
This research aims at describing the headmaster candidate's competence in Jombang, East Java, Indonesia. This competence involved personality, social, managerial, supervision, and entrepreneurship for headmaster candidates. This research used a quantitative approach with a descriptive design. The population of this research involved all elementary school teachers in Jombang, East Java who fulfilled the requirements to be a headmaster. The sample used in this research was saturation sample including 40 headmaster candidates. The research results showed that the leadership potential level of the headmaster candidates in terms of personality, social, managerial, supervision and entrepreneurship was categorized as high.
\end{abstract}

Keywords-analysis; competence; headmaster candidate's

\section{INTRODUCTION}

A headmaster is a central figure in attempting to enhance the quality, relevance and competence potential of education. The success of school in implementing the education programs should be supported by the effectiveness of headmaster [1]. As a leader, a headmaster is expected to be able to facilitate the success of strengthening the management, accountability, and education public imaging. The headmaster's success in realizing the education quality is absolutely supported by his/her competence mastering in running the duty, role as well as function as a headmaster. Therefore, a headmaster should implement an effective leadership to do his/her duty effectively.
A headmaster, basically, is a leader who is able to drive, influence, motivate and direct the others in the organization or education institution to reach the goal determined. Mulyasa (2004:182) states that the duty and responsibility of headmaster are related to all activities in the school. A headmaster should be able to mobilize and empower them to reach the education goal effectively and efficiently.

The headmaster's role as a leader is definitely important and thus in recruiting them, the potential of a headmaster candidate should be identified systematically. A headmaster having leadership potential is expected to create a new condition in the school in which he/she is positioned. The new condition involves the effort of enhancing the education quality in the school more effectively. There are some competences that should be belonged to a headmaster as stated in the Rule of National Education Ministry Number 13, 2007 about Standard of Headmaster of School/Islamic School. The competence standard includes the competence of personality, social, managerial, seupervision and entrepreneurship [2].

In line with the content of the rule mentioned above, the Education Institution of Jombang, East Java conducted education and training for elementary school headmaster candidates. The focus of the agenda was aiming at knowing the leadership potential of headmaster candidates in understanding problems, behaving and making decision with logical reason, systematical and applicative. Therefore, in that chance, the researcher tried to reveal the competence of headmaster candidates.

\section{METHODS}

This research attempted to know the potential of headmaster candidates from the aspect of competence that 
should they have. From the aspect of problem and goal, this research used a quantitative approach with a descriptive method design. This research was conducted when the agenda of education and training for elementary headmaster candidates was being held in Jombang, East Java.

The sample used in this research was saturation sample in which all participants of education and training - the headmaster candidates - became the research object. The researcher assumed that all headmaster candidates had passed some recuruitment stages in the headmaster candidate selection.

The research data were obtained through questionnaire with Likert scale as the model measurement scale. The data analysis technique used was descriptive analysis technique with quantitative approach.

\section{RESULT}

The data description of competence level of headmaster candidate included: competence of personality, managerial, entrepeneurship, supervision and social. The all competences are presented in detail as follow:

a. Personality Competence

Based on the analysis result, it was found that $45 \%$ of headmaster candidates or 18 people of them in Jombang had a very high personality competence. Meanwhile, most of the candidates $-52 \%$ of them - or 21 candidates had a high personality competence. For moderate category, there was only one person or $2,5 \%$ of candidates and there was no $(0 \%)$ candidate who had a low personality competence. To make them more feasible, we can see the description in figure 1 .

Seeing the figure above, it can be highlighted that most of the elementary school headmaster candidates in Jombang had a high level of personality competence. We can see it from the mean was 29,95. The mean value was in 25,27 - 30,35 class interval.

b. Social Competence

Social competence level of elementary headmaster candidates in Jombang, East Java was 27,5\% of candidates or 11 candidates were categorized as very high, $50 \%$ of candidates or 20 candidates had a high social competence level, 17,5 of candidates or 7 candidates had a moderate social competence level, and only $5 \%$ of candidates or 2 candidates had a low social competence level. In addition, there was no candidate who was categorized as very low level. The description of social competence level of elementary school headmaster candidates in Jombang, East Java is presented in figure 2 .

Based on the results of calculation, it was found that the social competence level of elementary school headmaster candidates in Jombang, East Java, was categorized as high that was proven by the mean value was 27,53 which was in the $24,87-29,82$ class interval.

c. Managerial Competence

The managerial competence levels of the elementary school headmaster candidates were $22,5 \%$ of candidates or 9 candaidates had a very high level, $67,5 \%$ of candidates or 27 candidates had a high level, only $10 \%$ of candidates or 4 candidates who had a low level and no one who was categorized as very low level. The detailed description of managerial competence level of elementary school headmaster candidates in Jombang, East Java was presented in figure 3 .

Based on the calculation results, it was found that the managerial competence level of elementary school headmaster candidates in Jombang, East Java was in the high level by seeing the mean value that was in $51,96-62,28$ class interval.

\section{d. Entrepeneurship Competence}

Based on the analysis result of entrepreneurship competence, it was found that the entrepreneurship competence level of elementary school headmaster candidates in Jombang, East Java reached the mean value of 34,40 that was in 30,23 - 35,97 class interval. The classification of entrepreneurship competence level is visualized in figure 4.

Based on the figure 4, it can be highlighted that the average of entrepreneurship competence level of the elementary school headmaster candidates in Jombang, East Java was categorized as high (47\% of candidates or 19 candidates). Only a half - 42,5\% - of the candidates showed a very high category and only $5 \%$ of candidates were categorized as moderate and low, and no one was categorized as very low. Therefore, it can be concluded that the entrepreneurship competence level of elementary school headmaster candidates in Jombang, East Java was categorized as high.

\section{e. Supervision Competence}

Based on the analysis result of supervision competence component, it can be concluded that the competence level of elementary school headmaster candidates in Jombang, East Java had a mean 21,79 with 18,95 22,60 class interval. The classification of supervision competence level is visualized in figure 5 .

Based on figure 5, it can be highlighted that the entrepreneurship competence level average of the elementary school headmaster candidates in Jombang, East Java was categorized as high, that was $52,5 \%$ of candidates or about 21 people. Additionally, $37,5 \%$ of candidates showed a very high category while only $10 \%$ of candidates showed a moderate category and no one was categorized 
as low and very low. Therefore, it can be concluded that the supervision competence level of the elementary school headmaster candidates in Jombang, East Java was categorized as high.

The whole description of the competence levels of the elemengary school headmaster candidates in Jombang, East Java is visualized in figure 6 .

\section{DISCUSSION}

Based on the research results, it was described that the abilities or competences of elementary school headmaster candidates related to competence of personality, social, managerial, entrepreneurship and supervision were all categorized as high. In other words, they had a big chance to be a headmaster. This phenomenon was in line with the policies of government dealing with education one of which requires the headmaster should have some competences like what have been stated in The Rules of Ministry of National Education Number 13, 2007 about the Standard of Headmaster of school/Islamic school. The research result of Oedjoe (2004) revealed that the headmaster's leadership is one of factors supporting school in reaching the goal effectively and efficiently [4]. Therefore, the effectiveness of leadership can be seen through the implementation of the headmaster's duty and responsibility.

Being a headmaster does not mean merely chasing a position. More than that, a headmaster is the leader of education who should play the role to hold an effective school. [3] A headmaster has three main roles one of which is related to leadership. In playing the role of leadership, a headmaster should correlate and cooperate to both external and internal groups such as (1) school supervisor, (2) school council, (3) colleague, (4) parents, (5) society, and (6) the other stakeholders. Reinhartz \& Beach (2007) state that one of leadership principals needed by a headmaster to be successful in leading the school is he/she should produce a good vision. There are three elements to make an inspiring and sustainable vision. They are (1) the desired long term goal is meaningful, (2) giving a clear description of the intended future, and (3) values agreed to be obeyed should be clear [5].

An effective school is realized when the headmaster as a leader has a professional ability in managing his/her school and becomes an effective leader. Davis \& Thomas (1989) tell the characteristics of a headmaster as an effective leader involves: (1) characteristics and leadership ability, (2) problem solving ability, (3) social skill, and (4) knowledge and skill of leadership. The research results of Sutrisno (2000:46) mentions that a school is good or not is determined more by professional ability of the headmaster. Therefore, a headmaster should master the competence at least of: (formulating the activity program of school, (2) arranging the work procedure, (3) conducting monitoring, evaluating and supervising, and (4) enhancing the teachers's and students' discipline. [5] Effective leadership should include the characteristics of visioner, authoritative performance, firm, eloquent, aggressive, hardwork, consistent, bravem friendly, and smart. Manning \& Curtis (2003) also state that an effective leadership can be measured by the indicators of: (1) factual, (2) creating vision, (3) motivating, and (4) empowering staff.

\section{CONCLUSION}

Based on the data analysisi results, it can be concluded that: (1) the competence level of the elementary school headmaster candidates in Jombang was categorized as high with the mean value of 29,95 ; (2) the social competence level was categorized as high with the mean value of 27,52 ; (3) the managerial competence level was categorized as high with the mean value of 58,76; (4) the entrepreneurship competence level was categorized as high with the mean value of 34,40 ; and (5) the supervision competence level was also categorized as high with the mean level of 21,79 . In other words, it can be concluded that the whole candidates of the elementary school headmaster in Jombang, East Java were categorized proper and skillful to be appointed as a headmaster.

\section{ACKNOWLEDGEMENTS}

Thanks to the Government of Jombang especially the Department of Education who has facilitated the researchers to conduct research on the potential leadership of elementary school headmaster candidates in Jombang, East Java.

\section{REFERENCES}

[1] Rahayu, P., Mustiningsih, dan Sunandar, A. 2014. Peran Kepala Sekolah dalam Mewujudkan Variasi Pembelajaran Kooperatif. Manajemen Pendidikan, Volume 24 Nomor 3, Maret 2014.

[2] Peraturan Menteri Pendidikan Nasional Nomor 23 Tahun 2007 tentang Standar Kepala Sekolah/Madrasah.

[3] Oedjoe, M. R. 2004. Kefektifan Kepemimpinan Perempuan sebagai Kepala Sekolah. Jurnal Ilmu Pendidikan. Juni 2004, Jilid 2, Nomor 2, hml. $191-192$.

[4] Lunenberg, F.C. \& Orstein, A.C. 2000. Educational Administration: Concep and Practices. $3^{\text {th }}$ Edition. Belmont, CA: Wadsworth Thomson Learning.

[5] Blanchard, K. 2007. Leading at a Higher Level. Upper Sadle River, New Jersey: Prentice Hall.

[6]Bush, T. \& Coleman, M. 2000. Leadership and Strategic Management in Education. London: A Sage Publications Campany. 
[7] Manning, G. \& Curtis, K. 2003. The Art of Leadership. New York: Mc. Graw-Hill.

[8] Reinhartz, J. \& Beach, D, M. 2004. Educational Leadership Changin School, Changing Roles. New York: Pearson.

[9] Sutrisno. 2000. Pengalaman Mengelola Tenaga Kependidikan di Tingkat Sekolah. Jurnal Pendidikan dan Kebudayaan. Januari. Tahun ke-5, No.021, hlm. 40 . 